\title{
CREATIVE THINKING: REVIEWED FROM INFORMATION PROCESSING MODEL (IPM) FOR PRIMARY SCHOOL TEACHERS
}

\author{
Idam Ragil Widianto Atmojo, Sajidan, Widha Winarno, Ashadi \\ Universitas Sebelas Maret \\ idamragil@fkip.uns.ac.id
}

\section{Article History}

accepted 09/07/2018

approved 01/08/2018

published 17/09/2018

\section{Keywords}

creative, information processing model.

\begin{abstract}
Memory is a structured system and causes organisms to be able to record facts and use knowledge to guide their behavior. Memory is also said to be a tool that serves to capture, process and use it when needed. Memory takes place through three processes, namely encoding, storage, and retrieval. The brain works through the information process by processing information through sensory stimulation and storing it into memory and involving thinking activities. Increasing the potential for creative thinking, the incoming stimulus is determined by personal situational factors. The purpose of this literature study is to find out that creative thinking is the result of information processing that occurs in human memory. The results of this literature study show that situational factors that are external or attention getter and prominent characteristics such as visual movements, novelty, clarity (fluency), new and extraordinary stimuli attract attention so that they can influence positive perception that goes into short-term memory. Through thinking activities, one's ideas and concepts developed through the process of relationships between the parts of information stored in him. Thinking is done to understand reality in order to make decisions (decision making), problem-solving (problem-solving) and produce new ones (creativity).
\end{abstract}

Social, Humanities, and Education Studies (SHEs): Conference Series https://jurnal.uns.ac.id/shes
p-ISSN 2620-9284 e-ISSN 2620-9292 


\section{PENDAHULUAN}

Teori pemrosesan informasi termasuk dalam teori kognitif tentang belajar yang menjelaskan pemrosesan, penyimpanan, dan pemanggilan kembali pengetahuan dari otak. Teori ini menjelaskan proses seseorang memperoleh sejumlah informasi dan dapat diingat dalam waktu yang cukup lama oleh (Gurbin, 2015;Hemmatjo, Motamedzade, Aliabadi, Kalatpour, \& Farhadian, 2017).

Komponen pertama dari sistem memori yang dijumpai oleh informasi yang diterima adalah registrasi penginderaan. Registrasi penginderaan menerima sejumlah besar informasi dari indera dan menyimpannya dalam waktu yang sangat singkat, tidak lebih dari dua detik. Terjadi suatu proses terhadap informasi yang disimpan dalam register penginderaan, maka dengan cepat informasi hilang.Keberadaan register penginderaan mempunyai dua implikasi penting dalam pendidikan. Pertama, menyimpan perhatian pada suatu informasi yang harus diingat. Kedua, memerlukan waktu untuk membawa semua informasi yang dilihat dalam waktu singkat masuk ke dalam kesadaran. Interpretasi seseorang terhadap rangsangan dikatakan sebagai persepsi. Persepsi dari stimulus tidak langsung seperti penerimaan stimulus, karena persepsi dipengaruhi status mental, pengalaman masa lalu, pengetahuan, motivasi, dan banyak faktor lain (Tacikowski, Freiburghaus, \& Ehrsson, 2017).

Informasi yang dipersepsi dan mendapat perhatian, ditransfer ke komponen kedua dari sistem memori, yaitu memori jangka pendek. Memori jangka pendek merupakan sistem penyimpanan informasi dalam jumlah terbatas hanya dalam beberapa detik. Satu cara untuk menyimpan informasi dalam memori jangka pendek adalah memikirkan tentang informasi itu atau mengungkapkannya berkali-kali (Hughes, Chamberland, Tremblay, \& Jones, 2016)

Memori jangka panjang merupakan bagian dari sistem memori tempat menyimpan informasi untuk periode panjang. Menurut (Unsworth, 2017)membagi memori jangka panjang menjadi tiga bagian, yaitu memori episodik, yaitu bagian memori jangka panjang yang menyimpan gambaran dari pengalaman-pangalaman pribadi; Memori semantik, yaitu suatu bagian dari memori jangka panjang yang menyimpan fakta dan pengetahuan umum; dan memori prosedural adalah memori yang menyimpan informasi tentang bagaimana melakukan sesuatu.

\section{PEMBAHASAN}

\section{Berpikir Kreatif}

Kreativitas merupakan produk berpikir kreatif. Berpikir kreatif merupakan suatu proses yang digunakan ketika memunculkan suatu ide baru. Hal itu menggabungkan ide-ide yang sebelumnya yang belum dilakukan. Berpikir kreatif merupakan suatu aktifitas mental yang memperhatikan keaslian dan wawasan (ide)(Alfonso-benlliure \& Romo, 2016;An, Song, \& Carr, 2016).

Unsur kreatif diperlukan dalam proses berpikir untuk menyelesaikan masalah. Semakin kreatif seseorang, semakin banyak alternatif penyelesaiannya. Berpikir merupakan instrumen psikis paling penting. Melalui berpikir dapat lebih mudah mengatasi berbagai masalah dalam hidup (Egan, Maguire, Christophers, \& Rooney, 2017).

Berpikir kreatif merupakan salah satu cara yang dianjurkan, karena dengan cara itu seseorang mampu melihat persoalan dari banyak perspektif. Seorang pemikir kreatif menghasilkan lebih banyak alternatif untuk memecahkan suatu masalah. Agar mampu berpikir secara kreatif, pikiran harus dioptimalkan pada setiap tahap yang dilalui. Empat tahap pemikiran tersebut meliputi preparasi, 
inkubasi, iluminasi, dan verifikasi(Bourgeois-bougrine, Buisine, Vandendriessche, Glaveanu, \& Lubart, 2017).

Pada tahap preparasi, pikiran harus mendapat sebanyak mungkin informasi yang relevan dengan masalah yang sedang dihadapinya. Kemudian informasi itu diproses secara analogis untuk menjawab pertanyaan yang diajukan pada tahap orientasi. Pikirannya harus benar-benar dioptimakan untuk mencari pemecahan masalah melalui hubungan antara inti permasalahan, aspek masalah, serta informasi yang dimiliki.Tahap Inkubasi merupakan tahap berfikir kreatif dan pengatasan masalah tentang kejadian mental yang sebelumnya digerakkan oleh persiapan yang direncanakan secara intensif, mencapai pencerahan mandiri sehingga tercapai pemahaman, yang mengarah pada pengatasan masalah. Pada tahap inkubasi, ketika proses pemecahan masalah menemui jalan buntu, biarkan pikiran beristirahat sebentar. Sementara itu pikiran bawah sadar terus bekerja secara otomatis mencari pemecahan masalah. Proses inkubasi yang berlangsung sangat tergantung pada informasi yang diserap oleh pikiran. Semakin banyak informasi, semakin banyak bahan yang dapat dimanfaatkan dalam proses inkubasi. Proses berpikir tentang suatu masalah secara bawah sadar ketika terlibat dalam kegiatan lain.Ciri-ciri utama tahap inkubasi banyak tergantung dari persiapanyang intensif dan berhati-hati. Inkubasi tidak memerlukan kesadaran berpikir dalam menangani masalah.Berfungsinya inkubasi saat kondisi optimum terjadi melalui relaksasi atau istirahat kesadaran berpikir tentang masalah tersebut, perhatian ditujukan pada masalah-masalah yang lain melalui rangkaian inkubasi.Inkubasi meningkatkan berfungsinya belahan otak kanan atau imajinasi kreatif dengan permunculan pengatasan masalah kreatif.Pada proses iluminasi, proses inkubasi berakhir karena mulai mendapatkan inspirasi serta serangkaian pengertian (insight) yang dianggap dapat memecahkan masalah. Pada tahap ini sebaiknya diupayakan untuk memperjelas pengertian yang muncul, sehingga daya imajinasi memudahkan upaya tersebut.Pada tahap terakhir yakni verifikasi. Tahap ini harus menguji dan menilai secara kritis solusi yang diajukan pada tahap iluminasi, ternyata cara yang diajukan tidak dapat memecahkan masalah, sebaiknya kembali menjalani keempat tahap kembali, untuk mencari inspirasi baru yang lebih tepat (Yates \& Twigg, 2017;Costa, Páez, Sánchez, Garaigordobil, \& Gondim, 2015;Fischer, Oget, \& Cavallucci, 2016).

\section{Proses Berpikir Kreatif Hasil Dari Pemprosesan Informasi}

Dalam situasi pendidikan, proses belajar mengajar merupakan salah satu dari bentuk kegiatan kreatif. Melalui proses belajar mengajar, kreativitas siswa dapat dipupuk dan dikembangkan. Kreativitas peserta didik dapat muncul sewaktu-waktu pada sembarang tempat, sehingga perlu dilatih agar kemunculannya tidak sewaktuwaktu pada sembarang tempat, tetapi kreativitas ini muncul pada waktu menghadapi permasalahan. Menurut (Susnea, Pecheanu, \& Tudorie, 2015)kreativitas adalah perkembangan dan keinginan; pikiran yang menumpahkan cara berpikir yang tidak konvensional menuntun menuju lompatan besar dalam pengetahuan dan aplikasinya.

Menurut memandang kreativitas sebagai individu yang kreatif. Mendefinisikan kreativitas sebagai novelty, fluency, flexibility, dan originality. Lain halnya dengan (Salavera, Usán, Chaverri, Gracia, \& Aure, 2017)yang memandang kreativitas sebagai proses yang kreatif. Mendefinisikan kreativitas sebagai berikut: "Creativity is the forming of associative elements into new combination which either meet specified requirements or are in some ways useful. The more mutually remote the elements of thr new combination the more creative the process of solution".

Konsep dan pengembangan kreativitas bisa dilakukan dengan bertitik tolak pada pribadi, pendorong, proses dan produk. Aspek pribadi menekankan pada 
pemahaman bahwa peserta didik adalah pribadi yang unik. Oleh karenanya, pendidik haruslah menghargai bakat dan minat yang khas dari setiap peserta didik. Perlu diberi kesempatan dan kebebasan mewujudkan kreativitas. Kreativitas juga dapat ditinjau dari aspek pendorong, yakni suatu kondisi yang memungkinkan peserta didik berprilaku kreatif. Sedangkan kreativitas sebagai proses lebih menekankan pada pemahaman kemampuan peserta didik menciptakan sesuatu yang baru, paling tidak menemukan hubungan-hubungan jawaban antarberbagai unsur. Ketiga aspek inilah akhirnya yang menentukan kualitas produk kreativitas (Soh, 2017;Susnea et al., 2015).

Dalam upaya menjelaskan bagaimana suatu informasi (pesan pengajaran) diterima, disandi, disimpan dan dimunculkan kembali dari ingatan serta dimanfaatkan dan diperlukan, telah dikembangkan sejumlah teori dan model pemrosesan informasi oleh(Gurbin, 2015; Hemmatjo et al., 2017). Teori-teori tersebut umumnya berpijak pada tiga asumsi (Cookson, Hazeltine, \& Schumacher, 2016)yaitu: bahwa antara stimulus dan respon terdapat suatu seri tahapan pemrosesan informasi pada masing-masing tahapan dibutuhkan sejumlah waktu tertentu, stimulus yang diproses melalui tahapan-tahapan tadi mengalami perubahan bentuk ataupun isinya, salah satu dari tahapan mempunyai kapasitas yang terbatas.

Dari ketiga asumsi tersebut, dikembangkan teori tentang komponen struktur dan pengatur alur pemrosesan informasi (proses control) hingga terbentuk proses berpikir kreatif. Kompenen pemrosesan dipilih menjadi tiga berdasarkan perbedaan fungsi, kapasitas, bentuk informasi. Ketiga komponen tersebut Sensory receptor, Working memory dan Long term memory yang disubtitusikan dengan tahapan berpikir kreatif yaitu preparasi, inkubasi, iluminasi, dan verifikasi (Hughes et al., 2016; Unsworth, 2017;Gurbin, 2015).

Sejalan dengan teori pemrosesan informasi, (Tacikowski et al., 2017)mengemukakan bahwa perolehan pengetahuan baru merupakan fungsi srtuktur kognitif yang telah dimiliki individu. mengatakan pengetahuan ditata didalam struktur kognitif secara hirarkhis. Ini berarti pengetahuan yang lebih umum dan abstrak yang diperoleh lebih dulu oleh individu dapat mempermudah perolehan pengetahuan baru yang rinci Proses pengolahan informasi dalam ingatan dimulai dari proses penyandian informasi (encoding). Pada tahap ini sama dengan proses preparasi pada proses berpikir kreatif. Diikuti dengan penyimpanan informasi (storage), pada tahap ini terjadi proses inkubasi dan iluminasi pada proses berpikir kreatif. Diakhiri dengan mengungkapkan kembali informasi-informasi yang telah disimpan dalam ingatan (retrieval). Tahap terakhir ini terjadi proses verfikasi pada proses berpikir kreatif. Ingatan terdiri dari struktur informasi yang terorganisasi dan proses penelusuran bergerak secara hirarkhis, dari informasi yang paling umum dan inklusif ke informasi yang paling umum dan rinci, sampai informasi yang diinginkan diperoleh (Herzmann, Minor, \& Adkins, 2016).

Proses hubungan antara proses informasi dengan berpikir kreatif dapat dilihat pada gambar di bawah ini 


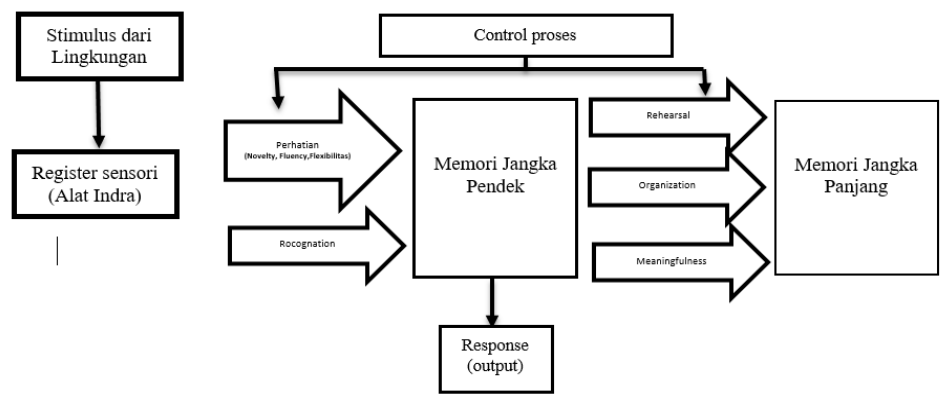

Gambar Bagan Proses Sistem Informasi

Sumber: (Unsworth, 2017;Hughes et al., 2016;Hemmatjo et al., 2017;Gurbin, 2015)

Secara rinci, (Unsworth, 2017; Hughes et al., 2016; Hemmatjo et al., 2017;Gurbin, 2015)memaparkan pemrosesan informasi sebagai berikut: Pertamatama, manusia menangkap informasi dari lingkungan melalui organ-organ sensorisnya (sistem indra manusia). Beberapa informasi disaring (diabaikan) pada tingkat sensoris, kemudian sisanya dimasukkan ke dalam ingatan jangka pendek (kesadaran), terjadi proses preparasi pada proses berpikir kreatif. Hal ini ditentukan olehfaktor-faktor situasional personal. Faktor situasional yang bersifat eksternal atau penarik perhatian (attention getter) dansifat-sifat yang menonjol, seperti :gerakansecara visual, kebaruan (novelty) dankejelasan. Hal ini dikarenakan stimulus yang barudanluarbiasa, berbeda, akanmenarikperhatian. Sehingga dapat berpengaruh positif persepsi yang akan masuk ke memori jangka pendek.

Ingatan jangka pendek mempunyai kapasitas pemeliharaan informasi yang terbatas sehingga kandungannya harus diproses sedemikian rupa (misalnya dengan faktor situasional), apabila informasi tersebut tidak diproses maka informasi tersebut lenyap dengan cepat. Ketika informasi diproses dari ingatan jangka pendek (short-term memory) dapat ditransfer ke dalam ingatan jangka panjang (long-term memory). Tahap STM ini terjadi proses inkubasi dan iluminasi pada proses berpikir kreatif. Ingatan jangka panjang (Long-Term Memory) merupakan hal penting dalam proses belajar. Tempat penyimpanan jangka panjang mengandung informasi labora (pengetahuan deklaratif) dan informasi mengenai bagaimana cara mengerjakan sesuatu (disebut pengetahuan laborativ). Pada tahap ketiga ini terjadi proses verifikasi pada proses berpikir kreatif karena tahap ini menguji dan menilai secara kritis solusi yang diajukan pada tahap iluminasi. Berpikir dilakukan untuk memahami realitas dalam rangka membuat keputusan (decision making), pemecahan masalah (problem solving) dan menghasilkan yang baru (creativity).

\section{SIMPULAN}

Berdasarkanstudi literature berpikir kreatif merupakan hasil dari pemprosesan informasi yang terjadi pada memori manusia.Memori berlangsung melalui tiga proses yaitu encoding, storage, dan retrieval. Tahapan berpikir kreatif yaitu preparasi, inkubasi, iluminasi, dan verifikasi.Tahapan ini berhubungan dengan pemprosesan informasi pada otak yang terdiri dari penerimaan rangsang (preparasi), proses STM (inkubasidaniluminasi), dan proses LTM (verifikasi). Otak bekerja melalui proses informasi dengan memproses informasi melalui rangsangan indra dan menyimpan menjadi memori serta melibatkan kegiatan berpikir. Berpikir menunjukkan berbagai kegiatan yang melibatkan penggunaan konsep dan lambang sebagai pengganti objek dan peristiwa. Berpikir dilakukan untuk memahami realitas dalam rangka membuat keputusan (decision making), pemecahan masalah (problem solving) dan menghasilkan yang baru (creativity). 


\section{DAFTAR PUSTAKA}

Alfonso-benlliure, V., \& Romo, M. (2016). Creativity development trajectories in Elementary Education: Differences in divergent and evaluative skills. Thinking Skills and Creativity, 19, 160-174. https://doi.org/10.1016/j.tsc.2015.11.003

An, D., Song, Y., \& Carr, M. (2016). A comparison of two models of creativity: Divergent thinking and creative expert performance. PAID, 90, 78-84. https://doi.org/10.1016/j.paid.2015.10.040

Bourgeois-bougrine, S., Buisine, S., Vandendriessche, C., Glaveanu, V., \& Lubart, T. (2017). Engineering students 'use of creativity and development tools in conceptual product design: What, when and how? Thinking Skills and Creativity, 24, 104-117. https://doi.org/10.1016/j.tsc.2017.02.016

Cookson, S. L., Hazeltine, E., \& Schumacher, E. H. (2016). Neural representation of stimulus-response associations during task preparation. Brain Research, 1648, 496-505. https://doi.org/10.1016/j.brainres.2016.08.014

Costa, S., Páez, D., Sánchez, F., Garaigordobil, M., \& Gondim, S. (2015). Journal of Work and Organizational Psychology Personal factors of creativity: A second order meta-analysis. Journal of Work and Organizational Psychology, 31(3), 165-173. https://doi.org/10.1016/j.rpto.2015.06.002

Egan, A., Maguire, R., Christophers, L., \& Rooney, B. (2017). Developing creativity in higher education for 21st century learners: A protocol for a scoping review. International Journal of Educational Research, 82, 21-27. https://doi.org/10.1016/j.ijer.2016.12.004

Fischer, S., Oget, D., \& Cavallucci, D. (2016). The evaluation of creativity from the perspective of subject matter and training in higher education: Issues, constraints and limitations. Thinking Skills and Creativity, 19, 123-135. https://doi.org/10.1016/j.tsc.2015.10.002

Gurbin, T. (2015). Enlivening The Machinist Perspective: Humanising The Information Processing Theory With Social And Cultural Influences. Procedia Social and Behavioral Sciences, 197(February), 2331-2338. https://doi.org/10.1016/j.sbspro.2015.07.263

Hemmatjo, R., Motamedzade, M., Aliabadi, M., Kalatpour, O., \& Farhadian, M. (2017). The Effect of Various Hot Environments on Physiological Responses and Information Processing Performance Following Fire fi ghting Activities in a Smoke-Diving Room. Safety and Health at Work, 1-7. https://doi.org/10.1016/j.shaw.2017.02.003

Herzmann, G., Minor, G., \& Adkins, M. (2016). Neural correlates of memory encoding and recognition for own-race and other-race faces in an associativememory task. Brain Research, (October), 1-10. https://doi.org/10.1016/j.brainres.2016.10.028

Hughes, R. W., Chamberland, C., Tremblay, S., \& Jones, D. M. (2016). Perceptual- 
motor determinants of auditory-verbal serial short-term memory q. Journal of Memory and Language, 90, 126-146. https://doi.org/10.1016/j.jml.2016.04.006

Salavera, C., Usán, P., Chaverri, I., Gracia, N., \& Aure, P. (2017). Emotional intelligence and creativity in first- and second-year primary school children. Procedia - Social and Behavioral Sciences, 237(June 2016), 1179-1183. https://doi.org/10.1016/j.sbspro.2017.02.176

Soh, K. (2017). Fostering student creativity through teacher behaviors. Thinking Skills and Creativity, 23, 58-66. https://doi.org/10.1016/j.tsc.2016.11.002

Susnea, I., Pecheanu, E., \& Tudorie, C. (2015). Initiatives towards an education for creativity. Procedia - Social and Behavioral Sciences, 180(November 2014), 1520-1526. https://doi.org/10.1016/j.sbspro.2015.02.301

Tacikowski, P., Freiburghaus, T., \& Ehrsson, H. H. (2017). Journal of Experimental Social Psychology Goal-directed processing of self-relevant information is associated with less cognitive interference than the processing of information about other people. Journal of Experimental Social Psychology, 68, 93-100. https://doi.org/10.1016/j.jesp.2016.05.007

Unsworth, N. (2017). Examining the dynamics of strategic search from long-term memory. Journal of Memory and Language, 93, 135-153. https://doi.org/10.1016/j.jml.2016.09.005

Yates, E., \& Twigg, E. (2017). Developing creativity in early childhood studies students. Thinking Skills and Creativity, 23, 42-57. https://doi.org/10.1016/j.tsc.2016.11.001 